\title{
TAXONOMY AMONG TRIPLETS: OPENING THE BLACK BOX
}

\author{
Rehab Iftikhar \\ Luiss Guido Carli University, Italy \\ Ralf Müller \\ BI Norwegian Business School, Norway
}

\begin{abstract}
In this paper, we discuss differences among risk, crisis, and disaster. These concepts are commonly and interchangeably used but are conceptually different from each other. It is pivotal to understand their differences in order to manage them. Within each of these concepts, the paper offers an overview of the literature, particularly the definitions, types, characteristics, and management approaches to develop a taxonomy of risk, crisis, and disaster. Sixteen dimensions of difference were identified for the taxonomy. Further distinguishing dimensions are developed. By plotting existing literature against the origin, mitigation, and recovery publication of each of these concepts, an agenda of future research topics is developed.
\end{abstract}

Keywords: risk, crisis, disaster, taxonomy.

Cite this Article: Rehab Iftikhar and Ralf Müller, Taxonomy Among Triplets: Opening the Black Box, International Journal of Management, 10 (2), 2019, pp. 63-85. http://iaeme.com/Home/issue/IJM?Volume=10\&Issue=2

\section{INTRODUCTION}

Risk, crisis, and disaster are terms frequently used to describe the status of organizations. Often all these terms are used by different people to describe the same situation. But what is the difference? If in a project review meeting the project manager describes the project as being at risk, the project sponsor it as being in a crisis and the business unit manager as a disaster, the questions arise: Who is right? What is the real status? Which reactions are appropriate for rescuing the situation? Risk, crisis and disaster are terms frequently used in management and increasingly discussed in contemporary research, but paradoxically neither implicitly or explicitly (universally) defined in relation to each other. Business and management researchers address risk and crisis more often as a topic than disaster management. One reason for this may be that risk and crisis occur more frequently in businesses, whereas disasters rarely occur there (Schenker-Wicki et al., 2010). Still, it remains unclear what characterizes each of these states and what the appropriate management actions are for each of them. Generally speaking, the terms risk, crisis, and disaster are interdisciplinary in character and ancillary (sharing a few properties) in nature. In daily life, the terms are frequently applied even though they are often not sufficiently distinct in their usage. Publications also often leave the individuality of each 
concept unaddressed. Hence, the present paper is among the first that made an attempt to differentiate among three concepts by building a taxonomy of distinguishing dimensions and contingent management actions. This is addressed conceptually, by using existing literature to explore the nature of each of these concepts and develop a related taxonomy.

The aim of the paper is to position the concepts of risk, crisis and disaster against each other by defining them, identifying their differences and commonalities, and to develop a list of characteristics and contingencies associated with each of these concepts, which allows to identify appropriate management action based on the particular state of either risk, crisis or disaster, as well as to identify areas for future research.

A review of existing literature showed that the terms are typically used, defined, and associated with management action only in isolation, not relative to each other. However, the same literature (see below) implies a contingency between risk, crisis and disaster and the related management action. For the improvement of the understanding of the relative definition of each concept and the associated actions, we ask the following research questions:

RQ1: What is the difference between risk, crisis, and disaster?

RQ2: What are the characteristics of each of these concepts?

RQ3: Which future research topics derive from an analysis of the three different concepts?

To address these questions, we

a) Review existing literature to identify how risk, crisis, and disaster have been conceptualized over the years by showing how earlier theoretical work enhanced the insight of these inter-related concepts.

b) Examine the overlap between them in order to clarify boundaries between the phenomena and to identify differences, to understand and manage these concepts, their required phases, and possible types.

c) Develop taxonomy with related dimensions to organize the existing literature and to resolves, some of the conceptual ambiguities, as well as to provide an impetus for future research into the role those different categories play in shaping the nature of these concepts. This paves the way for further empirical investigations.

d) Identify the types of management action related to each of these concepts. This allows for an understanding of the context specificity of management actions and economizing of the costs related to these actions.

e) Position existing publications along the main distinguishing dimensions of these concepts in order to identify areas of future research.

The taxonomy is supported and strengthened through analysis techniques developed herein, such as a continuum of risk, crisis and disaster, 3D diagrams to place key literature against distinguishing dimensions, and contingency tables for management action. Finally, we develop a model for understanding the evolution of these concepts, which reinforces the taxonomy and provides an overview of key publications.

Through the above, we advance the conceptual understanding of these terms, their differences, commonalities, and associated management actions. This reduces confusion, misunderstandings and transaction costs.

The results are of use for practitioners and researchers alike, as it will enhance their knowledge and clarity about these concepts in their daily business and academic life and economize on costs for managerial action. Through this, the paper will redress an important deficiency in management publications, that is, the lack of differentiation between risk, crisis, and disaster. 
This study is organized as follows. The following section describes the method used for selecting relevant literature, followed by a review of mainstream theories related to risk, crisis, and disaster. This proceeds into a section on taxonomy development, followed by a discussion section. Finally, conclusions are drawn and contributions are documented.

\section{METHODOLOGY}

The primary sources used for identifying literature were electronic databases (EBSCO Business Source complete, Google Scholar, and ISI web of science) by retrieving papers that were published in the business and management categories, with titles, abstracts, or keywords containing the terms "crisis, risk and disaster" or "crises, risks and disasters". This revealed 310 articles all published between 1963 and 2015. These were published in a variety of journal categories, indicating that these concepts and their perspectives are beginning to diffuse from the management area into fields such as Disaster Prevention and Management, Journal of Contingencies and Crisis Management, and Columbia Journal of World Business. Our initial list of journals included the Academy of Management Journal (AMJ), Academy of Management Executive (AME), Academy of Management Review (AMR), Administrative Science Quarterly (ASQ), Journal of Management Studies (JMS), Research Policy (RP), MIS Quarterly, Organization Science (OS), and Strategic Management Journal (SMJ). To these, we added three of the leading practitioner-oriented journals, namely, the California Management Review (CMR), Harvard Business Review (HBR), and MIT Sloan Management Review (MSM). We deployed a snowball approach by tracing references of articles found, to incorporate the most imperative research work which we didn't want to abscond but sometimes missed due to imperceptible reasons. The literature was selected for review based on its relevance to the topic under study. If an article had little to do with risk, crisis, and disaster, it was excluded from the collection. Our final sample included 121 publications. We incorporated both empirical (qualitative and quantitative) and conceptual and theoretical studies in the review. Moreover, the literature review identified 19 textbooks/reports relevant to our study. Books and reports have made valuable contributions to the topic under consideration.

\section{LITERATURE REVIEW}

In this section, we review the literature on risk, crisis, and disaster as selected through the abovementioned methodology. Subsequently, we develop taxonomy (Table 1). An overview of the key publications is provided in Appendix A (Table 2).

\subsection{Risk}

Risk is not a consistent concept. Different researchers have different views about risk. The definition of risk changed throughout history. It is a challenge to generally agree on the definition of risk (Zhang, 2011; Krane et al., 2012). Of many definitions of risk available, the ones deemed most appropriate (appropriate in term of explaining what can happen during risk, and what are the consequences of risk? (Kaplan, 1997: 408)) for the study are presented below.

Sicotte and Bourgault (2008: 468) relate risk to an "identifiable event that will have negative consequences". Risk can be defined as "the ambiguity associated with both potential gain and loss" (Solomon et al., 2000: 449), but mostly it is considered the possibility of suffering loss. Linsley and Shrives (2006: 389) define risk disclosures as "any information disclosing to readers on any opportunities, prospect, hazard, harm, thread or exposure that have already impacted or may impact upon the company or management in future".

Most definitions of risk comprise two dimensions: the probability associated with an undesirable event and the consequences of the occurrence of this event. Risk is also defined as "the degree of exposure to negative events and their probable consequences" (Wideman, 1986: 
26). Raz et al. (2002: 101) define risk as "undesired events that may cause delays, excessive spending, unsatisfactory results, safety or environmental hazards, and even total failure". Risks may come from the task itself, which can be characterized by uncertainty, complexity, and urgency, or from lack of resources or other constraints such as skills, or policy. While no one can avoid risk (just as no one can avoid natural disasters or fire). Good news is that you can plan for risk but you can only recover from disasters (Raz et al., 2002).

Raz et al. (2002) definition refer to uncertainty, which is often confused with risk. A few researchers (e.g. Meyer et al., 2002; Knight, 1921) draw a line between risk and uncertainty, where the former is measurable, insurable (predictable) and the latter unmeasurable and noninsurable (unpredictable). Risks are the known events which can be managed (Knight, 1921). Thus, risk is expected whereas uncertainty is an unexpected event. Related concepts in Appendix B outlines more details of the differences between risk and uncertainty.

Most people associated risks with possibilities or likelihoods of loss or harm (Brinkmann, 2013). Unless its positive impact, risk is more likely considered as "negative and undesirable consequences" (Gephart et al., 2009: 141; Maguire and Hardy, 2013: 232). It is necessary to determine the probabilities of undesirable events and their associated losses (Barki et al., 1993). With the exception of some practitioner publications, such as the PMI Guide to the Project Management Body of Knowledge (Project Management Institute, 2013), the literature associates risk only with the threat of negative outcomes, and positive outcomes are not considered to be a risk at all (Berkeley et al., 1991). A characteristic of an event carrying risk is that there is a probability that the event can give a certain result, and further that the result may have measurable or given consequences (Krane et al., 2012). Risk is a probabilistic event that can have predictable effects. Risk and its effect can be studied, mitigated and prevented (Heath et al., 2009).

\subsection{Crisis}

Crisis research developed in the 1960s and 1970s in the field of psychology, sociology and disaster response (Jaques, 2009). Crisis is characterized by a set of un-nesses like: un-familiar, un-expected, un-planned, un-pleasant, un-operational, and often un-imaginable and non-routine (Kouzmin, 2008; Oh et al., 2013). Crisis is unpredictable as they are unforeseen, immeasurable and unknowable (Seeger, 2002). However, there is a plethora of definitions which indicate researchers' difficulties in agreeing on a common designation of crisis. Typically, crisis is seen as a negative phenomenon, an event that menaces the organization (Valackiene, 2011). A crisis is assumed when there is a disruption for which no specific plans have been made. Although crises are rare, little is known about how to define crisis (Billings et al., 1980). A large number of definitions continues to bedevil and consensus of a definition has been problematic (Kouzmin, 2008). In this respect, the first important step is to clarify the notion of crisis. Due to this reason, we mentioned a few definitions in order to make it understandable what different scholars think about crisis.

Crisis has been defined in numerous ways. For example, Fearn-Banks (1996:1) defines crisis as "a major occurrence with a potentially negative outcome affecting an organization, company, or industry, as well as its public, products, services, or good name". According to Turner (1976: 378) crisis is an ill-structured and "precipitating event". Milburn et al. (1983: 1161) define crisis as a "situation in which organizational survival is perceived to be at stake". Others define crisis as "specific, unexpected, and non-routine event that threatens organizational goals" (Seeger et al., 1998: 233), or "a threat to the stability, core beliefs, goals of the organization and ultimately survival" (Ulmer \& Sellnow, 2002: 362). Coombs (1999) described it as "an unpredictable event that threatens to harm an organization and its stakeholders". Weick (1988: 305) argues that a crisis is a "low probability/high consequence 
event that threatens the most fundamental goals of the organization". Others see it as a "highly ambiguous situation where cause and effects are unknown" (Dutton, 1986; Quarantelli, 1988); "to have a low probability of occurring but threat to survival of organization, little time to respond" (Quarantelli, 1988) "and surprise for organization and need urgency for decision making" (Hermann, 1963: 65) to respond crisis.

The most widely cited definition is proposed by Pearson and Clair, they view a crisis as "a low-probability, high impact event that threatens the viability of the organization and is characterized by ambiguity of cause, effect, and means of resolution, as well as by a belief that decisions must be made swiftly" (1998: 60). The above definitions have some commonalities. First, a crisis is an unplanned event that has the potential of dismantling the internal and external structure of an organization. A crisis may affect not only the employees and other members internal to the organization but also key stakeholders external to the organization. Second, a crisis may occur in any organization. For example, non-profit organizations, governmental agencies, multinational organizations, and so forth, all are susceptible to a crisis (Barton, 1993). Finally, a crisis may affect the legitimacy of an organization. In the event of a crisis, influence on public perception may affect the survival of an organization. Crisis influences public perception in regards to issues involving cause, blame, response, resolution, and consequences. Presented in a negative light, the legitimacy of an organization may be threatened (Ray, 1999).

"The Chinese symbol for crisis combines two simpler symbols (Weji), (We) the symbol for danger and ( $\mathrm{Ji})$ the one for opportunity. Crisis is a time of danger, but it is also times of opportunity" (Starbuck et al., 1978: 135; Valackiene, 2011: 80). Crisis can have negative and positive outcomes. Crisis can be considered as an opportunity to change and opportunity to learn. It is an opportunity to change when warning signals are recognized before a crisis occurs. However, it is often only possible after the crisis, because warning signals are easier to detect after the crisis. Crisis warning signals can come from inside or outside the organization (Veil, 2011). Predicting a crisis is difficult (Carone \& Lorio, 2013). Due to the unpredictable nature of crises, it is difficult for scholars to study these events in real time (Pearson \& Clair, 1998: 74). There are two ways to deal with crises. The first is to prevent the crisis. Hence, a crisis is unimaginable so it is impossible to prevent them. The second is to prepare for a crisis, which is more realistic. Humans can merely foresight a few things and usually not unthinkable thinks the unknown unknowns (Hällgren \& Wilson, 2008).

\subsection{Disaster}

The history of disaster is as old as civilization itself. Disasters are large intractable and lethal events (Alexander, 1997). Any expected and unexpected event resulting in great damage to humans in term of life, environment, economy or quality of life in the present and future can be considered a disaster (Yi et al., 2010). Disasters are destructive and continue to cause loss of human life, environmental damage, disruption of infrastructure, and economic loss (Alexander, 1997; Altay \& Green, 2006). Loss is measured in terms of people affected and losses of life. Despite possible resilience, disasters affect large numbers of people and communities, for example by destroying homes, businesses, roads and causing damage in excess of billions of USD (Julca, 2012).

There is no single definition for disaster; the term is interpreted differently by different authors and institutions (Alexander, 1997; Siriwardena et al., 2013). Smith (2004: 12) viewed disaster as a "social phenomenon that occurs when a community suffers exceptional, nonroutine, levels of disruption and loss". Disaster can be defined as "a situation which overwhelms local capacity, necessitating a request to the national or international level for assistance, or is recognized by a multilateral agency or by at least two sources, such as national, regional or international assistance groups and the media" (Moe et al., 2007: 787). "As an acute, 
collectively experiences traumatic events with a sudden onset, and they can be both natural and man-made" (Norris et al., 2002: 208; United Nations, 2006). Disaster is also defined as "an unusual and dramatic event, in relatively short time span, causes enough death and destruction as to disrupt normal patterns of livings" (As cited in Dean and Payne, 2013 (Pampel, 2008)). The most recent definition is "a disaster is an event in which a society is pulled into serious danger and suffers human loss or material damage to the extent that the local social structure collapses and all or some of the essential functions of the society can no longer be fulfilled" (Schenker-Wicki et al., 2010: 339).

Disaster is categorized in man-made and natural disasters. Man-made disasters can be avoided whereas it is impossible to fully avoid or prevent natural disasters (Schenker-Wicki et al., 2010). There is an extensive literature on the frequency of natural disasters and their damages in contrast to man-made or technological disasters. Data is far more known for natural disasters than man-made equivalent. Natural disasters are far more damaging, they cause 10 times more fatalities then man-made disasters (Coleman, 2006). Natural disasters tend to include visible damage with clear stages of recovery in contrast to man-made disasters, which are usually less visible without warning and clear stages of recovery (Williams, 2008). However, this is beyond the scope of our paper. The demand for disaster management is increasing as numbers of disaster are growing (Coleman, 2006).

The review above shows a lack of holistic analyzes that treat risk, crisis, and disaster as integrated phenomena. It also shows a knowledge gap in terms of generally accepted definitions and positioning of risk, crisis, and disaster against each other. Furthermore, it also identifies the concepts underlying the terms as differing in type of origin, magnitude of impact, and required prevention and/or response, despite they are often interchangeable use in publications. The paper continues by developing a taxonomy of the terms to fill this knowledge gap.

\section{THE TAXONOMY}

Taxonomy is referred to as a classification based on scientific inquiry. Taxonomies are built through analysis of concepts and their systematic categorization. They are academically and managerially meaningful. Table 1 presents the related comparison and categorization of risk, crisis, and disaster.

This paper in specific and taxonomy, in general, helps to get insight into the differences of risk, crisis and disaster, which is a first step in considering how to manage and reduce or limit the impacts of such events. There has been a lack of holistic analyzes that treat risk, crisis, and disaster as integrated phenomena. Many links among the various aspects of them remain poorly understood (Alexander, 1997). We use word triplets as triplets share few characteristics. However, at the same time, they are different as well. They may be identical in look but they have different nature and habits. The same is the case with our research paper. Risk, crisis, and disaster all are events, but their nature is different. By reading numerous papers, we found that risk, crisis, and disaster are not only different in definition but the way they are managed; their management phase and their types, etc. all are different. We identified dimensions from prior literature, which were understated, in order to differentiate. Failure to understand this distinction results in exercises, which are not realistic. In this paper, we developed a general taxonomy model that can help to understand these concepts comprehensively. 
Table 1 Taxonomy among Triplets

\begin{tabular}{|c|c|c|}
\hline Risk & Crisis & Disaster \\
\hline \multicolumn{3}{|c|}{ Definition } \\
\hline $\begin{array}{l}\text { A risk is an "identifiable events that } \\
\text { will have negative consequences" } \\
\text { (Sicotte \& Bourgault, 2008: 468). }\end{array}$ & $\begin{array}{l}\text { One of the most cited and in our } \\
\text { opinion, more complete and } \\
\text { comprehensive definition of crisis is "a } \\
\text { low-probability, high impact event that } \\
\text { threatens the viability of the } \\
\text { organization and is characterized by } \\
\text { ambiguity of cause, effect, and means } \\
\text { of resolution, as well as by a belief that } \\
\text { decisions must be made swiftly" } \\
\text { (Pearson \& Clair, 1998: 60). }\end{array}$ & $\begin{array}{l}\text { In our point of view the most reliable } \\
\text { and recent definition for disaster is } \\
\text { "an event in which a society is } \\
\text { pulled into serious danger and } \\
\text { suffers human loss or material } \\
\text { damage to the extent that the local } \\
\text { social structure collapses and all or } \\
\text { some of the essential functions of the } \\
\text { society can no longer be fulfilled" } \\
\text { (Schenker-Wicki et al., 2010: 339). }\end{array}$ \\
\hline \multicolumn{3}{|c|}{ Management } \\
\hline $\begin{array}{l}\text { Risk management could be defined "as } \\
\text { a business process whose purpose is to } \\
\text { ensure that the organization is } \\
\text { protected against risks and their } \\
\text { effects" (Tah \& Carr, 2001). Risk } \\
\text { management is considered a } \\
\text { standalone discipline (Jaques, 2007). }\end{array}$ & $\begin{array}{l}\text { Crisis management is a "systematic } \\
\text { attempt by organizational members } \\
\text { with external stakeholders to avert } \\
\text { crises or to effectively manage those } \\
\text { that do occur" (Pearson \& Clair, 1998: } \\
\text { 61). }\end{array}$ & $\begin{array}{l}\text { "Collective term encompassing all } \\
\text { aspects of planning for and } \\
\text { responding to disasters including } \\
\text { both pre and post-disaster activities" } \\
\text { (Siriwardena et al., 2013: 177). } \\
\text { Disaster management is cross- } \\
\text { functional and inter-related } \\
\text { activities, not a standalone concept } \\
\text { (Jaques, 2007). }\end{array}$ \\
\hline \multicolumn{3}{|c|}{ Management phases } \\
\hline $\begin{array}{l}\text { Phases are risk identification, risk } \\
\text { analysis, risk prioritization, and } \\
\text { mapping, risk response planning and } \\
\text { risk monitoring (Boehm, 1991; } \\
\text { Kaliprasad, 2006) }\end{array}$ & $\begin{array}{l}\text { Consists of five phases: signal } \\
\text { detection, preparation and prevention, } \\
\text { damage containment, recovery, and } \\
\text { learning (Mitroff et al., 1987; Pearson } \\
\& \text { Mitroff, 1993; Mitroff, 1994). }\end{array}$ & $\begin{array}{l}\text { Predication, warning, emergency } \\
\text { relief, rehabilitation, and } \\
\text { reconstruction are the main phases } \\
\text { (Moe \& Pathranarakul, 2006; Moe et } \\
\text { al., 2007). }\end{array}$ \\
\hline \multicolumn{3}{|c|}{ Characteristic } \\
\hline $\begin{array}{l}\text { Potential future event; holds a certain } \\
\text { probability of occurrence; negative } \\
\text { consequences but risk can be planned. } \\
\text { (Nieto-Morote \& Ruz-Vila, 2011; } \\
\text { Yosha, 2012) }\end{array}$ & $\begin{array}{l}\text { Severe threat, ambiguity of cause and } \\
\text { effects, high uncertainty (informational } \\
\text { and situational), contain element of } \\
\text { surprise, and time pressure and urgency } \\
\text { of prompt decision (Hermann, 1963; } \\
\text { Hart et al., 1993; Coombs, 2004) is } \\
\text { often unanticipated and outside of } \\
\text { organizational control (Hermann, 1963; } \\
\text { Pearson \& Mitroff, 1993; Pearson \& } \\
\text { Clair, 1998). }\end{array}$ & $\begin{array}{l}\text { Loss of life; many reported affected; } \\
\text { a declaration of a state of } \\
\text { emergency; or call for international } \\
\text { assistance (Emergency Disasters } \\
\text { Database, 2013). Damage to the } \\
\text { physical, economic and social } \\
\text { infrastructure of a community } \\
\text { (Shaluf et al., 2003). }\end{array}$ \\
\hline \multicolumn{3}{|c|}{ Initiator } \\
\hline Individual/ organization & Individual/ organization & $\begin{array}{l}\text { Individual/industry/ } \\
\text { government/community }\end{array}$ \\
\hline \multicolumn{3}{|c|}{ Level of change/ management } \\
\hline $\begin{array}{l}\text { Operations - Day-to-day activities } \\
\text { are used for risk management. }\end{array}$ & $\begin{array}{l}\text { Tactics- means to attain goals (Quarantelli, } \\
\text { 1988) are used for crisis management. }\end{array}$ & $\begin{array}{l}\text { Strategy- general, long-term and } \\
\text { overall objectives (Quarantelli, } \\
\text { 1988) are used for disaster } \\
\text { management. }\end{array}$ \\
\hline \multicolumn{3}{|c|}{ Classification } \\
\hline $\begin{array}{l}\text { Operational risk (usually contains } \\
\text { day to day, internal activities and } \\
\text { requires managers do have control } \\
\text { over them) } \\
\text { Strategic risk (societal effects and } \\
\text { risks beyond the control of } \\
\text { managers) (Cabedo \& Tirado, 2004; } \\
\text { Krane et al., 2012). }\end{array}$ & $\begin{array}{l}\text { Both social/organizational and } \\
\text { technical/economic, each subdivided into } \\
\text { internal (caused by something within the } \\
\text { organization) } \\
\text { external (caused by something outside the } \\
\text { organization) (Mitroff et al., 1987; } \\
\text { Shrivastava \& Mitroff, 1987). }\end{array}$ & $\begin{array}{l}\text { Natural (an act of God, } \\
\text { uncontrollable) } \\
\text { Man-made (due to human error and } \\
\text { negligence) (Norris et al., 2002; } \\
\text { Shaluf et al., 2003; Williams, 2008). }\end{array}$ \\
\hline \multicolumn{3}{|c|}{ Nature } \\
\hline $\begin{array}{l}\text { External risks arise from events } \\
\text { outside the company and are often } \\
\text { beyond their influence or control. }\end{array}$ & $\begin{array}{l}\text { Every crisis is unique and influenced by } \\
\text { internal weakness and external threats } \\
\text { (Egelhoff \& Sen, 1992). }\end{array}$ & $\begin{array}{l}\text { External: e.g. earthquake as an act of } \\
\text { God. }\end{array}$ \\
\hline
\end{tabular}


Internal risks are within the ambit of an organization that are controllable and ought to be eliminated or avoided. (Berkeley et al., 1991; Hobday, 2000; Kaplan \& Mikes, 2012).
Intentional/expected (some actors committed the crisis purposefully) Unintentional/unexpected (the crisis event was not committed purposefully) (Coombs \& Holladay, 1996; Ponis \& Koronis, 2012).

\section{Type}

Technical/ economic (internal:

product/service defects, product recall, computer breakdown, defective information, bankruptcy), (external:

Internal risk: Market, financial; technological, management, completion, technical, operational, legal etc.

External risk: Political, social, economic, environmental etc. (Akintoye \& MacLeod, 1997; 2001; Senge \& Carstedt, 2001; Dey, 2009; Gil, 2009). Edwards \& Bowen, 1998; Jaafari, environmental destruction, natural disaster that (disrupt the major project \& service; destroy organizational information bases; eliminate key stakeholders), hostile takeovers)

Social/organizational crisis (internal: organizational breakdown,

miscommunication, on-site product tampering, illegal activities, sexual harassment, work-related homicide), (external: terrorism, executive kidnapping, off-site product tampering, labor strikes, product/ service boycotts) (Mitroff et al., 1987; Shrivastava \& Mitroff, 1987; Pearson \& Mitroff, 1993).

\section{Frequency}

High frequency/probability and relatively low impact event (Andriani \& Mckelvey, 2011).

Low probability but high impact event (Weick, 1988; Coombs, 2004; Oh et al., 2013).

\section{Stakeholders}

Organizational stakeholder: supplier, client, financer, employee, etc. Not external assistance is needed. An organization usually handles risk by themselves.
Organizational stakeholders: employee, government agencies, customer and financiers and shareholders.
Natural disaster such as droughts, earthquake, extreme temperature, floods, tsunamis, landslides, storms, hurricanes volcanoes and wildfires, hydro-meteorological, blizzards, cyclones, typhoons, torrential, tornadoes, and rains, etc.)

Man-made disaster like riots, infectious diseases, plane crashes, epidemics and war, terrorism, bioterrorism, pandemics, radiation like releases from nuclear power plant, poisoning, chemical spill, collapse and explosions at sites, etc. (Yi et al., 2010;

Smet et al., 2012)

\begin{tabular}{|c|c|c|}
\hline & & Mutter, 2008). \\
\hline \multicolumn{3}{|c|}{ Austerity (Intensity/Severity) } \\
\hline $\begin{array}{l}\text { Risk is known, predictable, and } \\
\text { measurable (Holt, 2004). These } \\
\text { events are common and occur more } \\
\text { frequently. It is impossible to avoid. } \\
\text { We can plan for risk (Maguire and } \\
\text { Hardy, 2013). }\end{array}$ & $\begin{array}{l}\text { Sudden, unexpected, negative, } \\
\text { dangerous event (Robert \& Lajtha, } \\
\text { 2002) unusual and abnormal event } \\
\text { and inevitable (Pearson and Clair, } \\
\text { 1998) for an organization } \\
\text { (Loosemore, 1998) and poses } \\
\text { financial reputations threat (Coombs, } \\
\text { 2007). }\end{array}$ & $\begin{array}{l}\text { Inevitable, unexpected, extremely rare } \\
\text { event with no control (Schenker-Wicki } \\
\text { et al., 2010; Smet et al., 2012). It is } \\
\text { almost impossible to fully prevent the } \\
\text { damage or neutralizing all negative } \\
\text { impact (McConnell \& Drennan, 2006). } \\
\text { We can only recover from a disaster; } \\
\text { we cannot escape and mitigate them. }\end{array}$ \\
\hline \multicolumn{3}{|c|}{ Impact } \\
\hline $\begin{array}{l}\text { Organizations strive for success. The } \\
\text { impact is a matter of success and } \\
\text { failure of the organization (Tah \& } \\
\text { Carr, 2001; Meyer et al., 2002). }\end{array}$ & $\begin{array}{l}\text { A crisis can have a short and long- } \\
\text { term impact on organization } \\
\text { (Coombs, 1999). Crisis deals mostly } \\
\text { with organizational survival (Mitroff } \\
\text { et al., 1987). A crisis can jeopardize } \\
\text { and decimate entire organizations } \\
\text { (Pearson \& Mitroff, 1993). }\end{array}$ & $\begin{array}{l}\text { Disasters are highly extreme events in } \\
\text { their effects (Cutter, 2003). They have } \\
\text { a high negative impact on the } \\
\text { community for longer periods of time. } \\
\text { Communities are struggling for their } \\
\text { survival. Disaster includes a high } \\
\text { degree of complexity (Shaluf et al., } \\
\text { 2003). }\end{array}$ \\
\hline \multicolumn{3}{|c|}{ Scale } \\
\hline $\begin{array}{l}\text { Expected, known-unknown } \\
\text { (identifiable but not possible to find } \\
\text { out when it will occur) and } \\
\text { unfavorable events. Small scale and } \\
\text { affecting the organization or project. }\end{array}$ & $\begin{array}{l}\text { Crises are event with large scale } \\
\text { damage (Mitroff et al., 1987; } \\
\text { Shrivastava \& Mitroff, 1987). They } \\
\text { are unidentifiable/ unpredictable; } \\
\text { there is often no alternative or }\end{array}$ & $\begin{array}{l}\text { Collapse of the system (Schenker- } \\
\text { Wicki et al., 2010) and chaos: the basic } \\
\text { structure is shaken; contingency plans } \\
\text { are insufficient (Meyer et al., 2002). } \\
\text { Large scale, highly complex and }\end{array}$ \\
\hline
\end{tabular}

Rare probability with high impact (Shaluf et al., 2003; McConnell \& Drennan, 2006).

Government as a major stakeholder. Non-governmental agencies (NGO, Armed forces, Disaster cell, International relief organizations, and special response teams) (Nateghi-A, 2000; Moe \& Pathranarakul, 2006; Mutter, 2008).

Inevitable, unexpected, extremely rare went with no control (Schenker-Wick almost impossible to fully prevent the damage or neutralizing all negative impact (McConnell \& Drennan, 2006). We can only recover from a disaster; we cannot escape and mitigate them.

Disasters are highly extreme events in their effects (Cutter, 2003). They have a high negative impact on the Communities are struggling for their survival. Disaster includes a high degree of complexity (Shaluf et al., 2003).

Collapse of the system (SchenkerWicki et al., 2010) and chaos: the basic are insufficient (Meyer et al., 2002). Large scale, highly complex and 


\begin{tabular}{|c|c|c|}
\hline Risk & Crisis & Disaster \\
\hline $\begin{array}{l}\text { Risks lead to deviation and disruption } \\
\text { (Wideman, 1986; Barki et al., 1993; } \\
\text { Krane et al., 2012). Risk can be } \\
\text { identified and mitigated through } \\
\text { alternative plans (Meyer et al., 2002). }\end{array}$ & $\begin{array}{l}\text { contingency plans (Meyer et al., } \\
\text { 2002). }\end{array}$ & $\begin{array}{l}\text { extraordinary event (Wei et al., 2009) } \\
\text { leads to devastation (Shaluf et al., } \\
\text { 2003). }\end{array}$ \\
\hline \multicolumn{3}{|c|}{ Scope } \\
\hline $\begin{array}{l}\text { Some of the risk effect on individual } \\
\text { organization and/or industry. It could } \\
\text { shift from industry to organization or } \\
\text { from organization to industry. }\end{array}$ & $\begin{array}{l}\text { Crises can hit anytime and anywhere } \\
\text { (Loosemore, 1998) in any firm large, } \\
\text { small, national or international (Shaluf } \\
\text { et al., 2003). Crises do not only affect } \\
\text { organizations but also industries and } \\
\text { sometimes the entire world (Reilly, } \\
\text { 1987). }\end{array}$ & $\begin{array}{l}\text { Affect the entire community or nation } \\
\text { (Wei et al., 2009) or the world. } \\
\text { Disasters shift from country/ies or } \\
\text { community to industry or } \\
\text { organization. }\end{array}$ \\
\hline \multicolumn{3}{|c|}{ Magnitude } \\
\hline $\begin{array}{l}\text { Risk usually disrupts the operational } \\
\text { activities, the consequences/ impact } \\
\text { are known and risk can be identifiable } \\
\text { beforehand (Knight, 1921; Holt, } \\
\text { 2004). }\end{array}$ & $\begin{array}{l}\text { Crisis is incomprehensible and } \\
\text { inevitable (Wan \& Yiu, 2009; Oh et al., } \\
\text { 2013). It is potentially a threat, } \\
\text { unpredictable and unanticipated event } \\
\text { (Coombs, 2004). A crisis is a high } \\
\text { magnitude event, a threat to the } \\
\text { viability and reputation of an } \\
\text { organization (Pearson \& Mitroff, } \\
\text { 1993). }\end{array}$ & $\begin{array}{l}\text { Disasters are potentially disastrous } \\
\text { and devastating and have severe } \\
\text { consequences (Siriwardena et al., } \\
\text { 2013) on a local, international or } \\
\text { global scale. }\end{array}$ \\
\hline
\end{tabular}

\subsection{Continuum}

The dimensions of the taxonomy along with their relationship with the three concepts of risk, crisis, and disaster are shown in Figure 1. The dimensions are probability (likeliness that an event will occur), impact (effect), intensity/severity (extremity or danger), scope (effect individual, organization/ industry or community), scale (how much would it damage), magnitude (size of disruption), frequency (number of occurrence) and predictability (degree to which a correct prediction or forecast can be made). The dimensions are the same for the risk, crisis, and disaster; however, the difference in their intensity would position these three concepts.

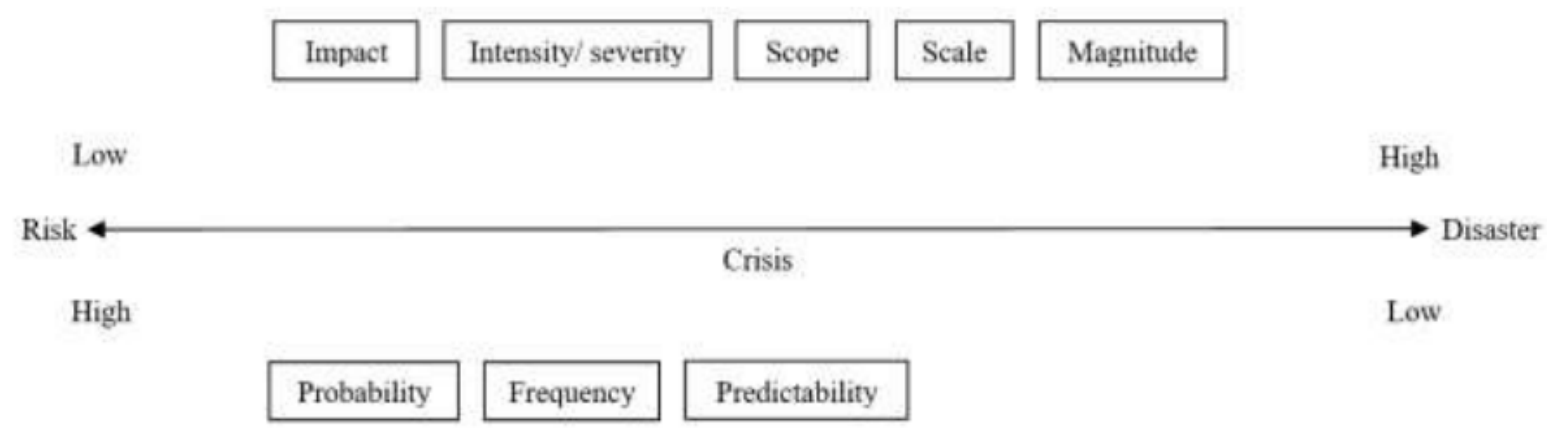

Figure 1 Positioning of risk, crisis, and disaster in the continuum by using key dimensions

Figure 1 shows a continuum with risk and disaster as extreme points and crisis in the middle. The boxes on the top of Figure 1 indicate those dimensions from Table 1 that increases when moving along the continuum from risk to disaster. For example, the impact increases when moving from risk to crisis or from crisis to disaster. The boxes on the lower side of Figure are those dimensions from Table 1 that decrease while moving along the continuum from risk to disaster. For example, predictability decreases when moving from risk to crisis or crisis to disaster. 


\subsection{The development of risk, crisis, and disaster in the literature}

The evolution of three terms in the literature is shown in Figure 2 by outlining how they evolved over the years, their first appearance in scientific journals, and their contribution to the development of new, but related terms. If we consider Knight's work (1921), disaster, risk, crisis, and related concepts fall under the category of risk or uncertainty, but through the passage of time, these concepts evolved with their own distinctiveness and positioning. Figure 2 intends to support future research by positioning the concepts and key literature that shaped the appearance of concepts over the years. Usually, contemporary researchers bewilder all these concepts, so this model could be a good example of concept distinctiveness over the years. It helps researchers to keep the distinctiveness of these concepts in their research as well. In order to use them immaculately, it is essential to understand their distinctiveness.

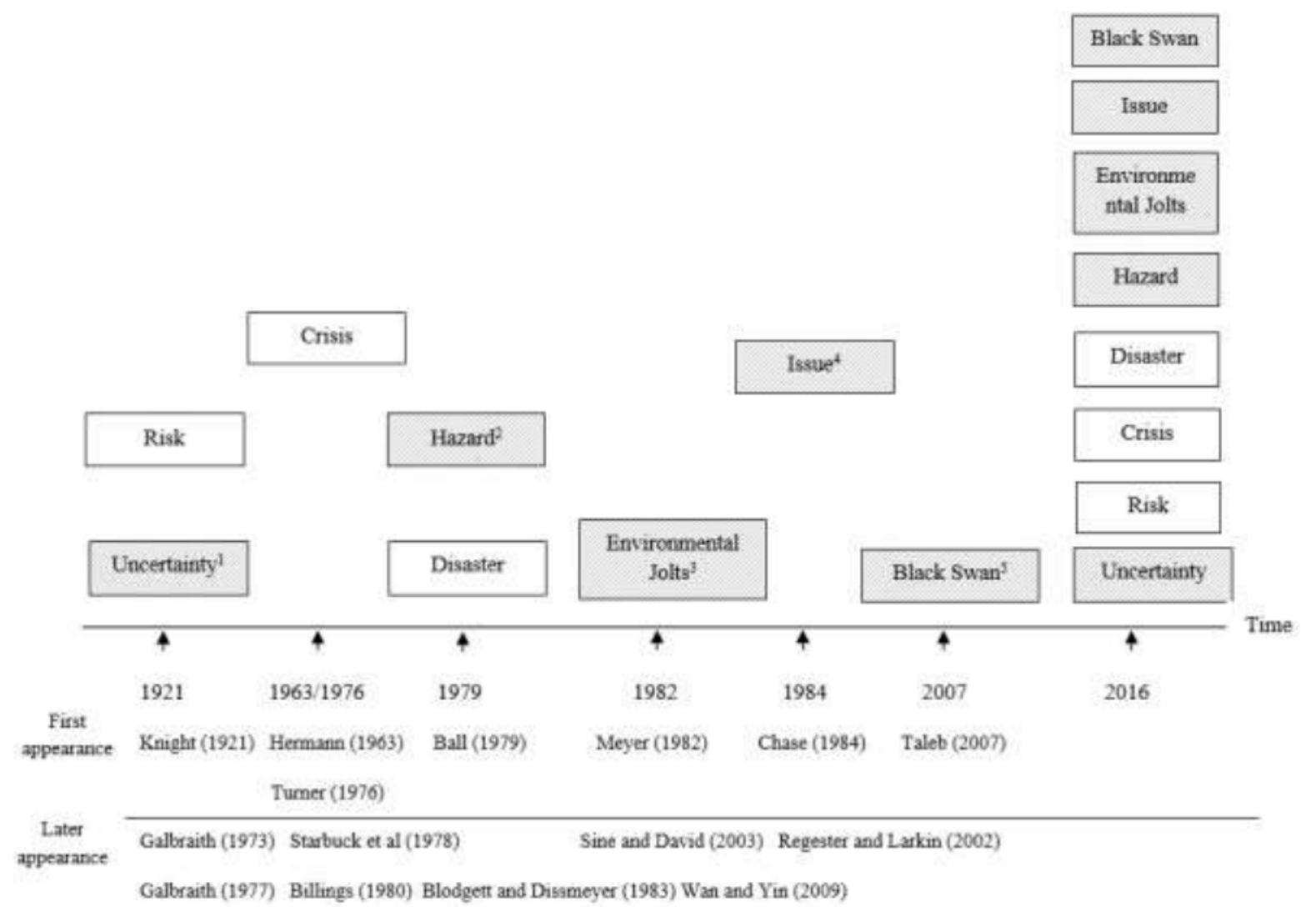

Figure 2 Evolution of risk, crisis, disaster and related concept (The shaded boxes are not the focus of the paper, but to avoid confusion, you can read details in endnotes)

\subsection{Future Research}

In the below 3D diagrams we identified areas for future research. We placed the key literature of risk, crisis, and disaster in 3D diagrams, along with the dominating dimensions in order to elucidate differences. We call these dimensions distinguishing dimensions. We identified three distinguishing dimensions i.e. nature of event (ongoing-extremely rare), goal (preventionresponse) and source (internal-external). So we position nature of event on the $\mathrm{X}$-axis, goal on $\mathrm{Y}$-axis and place source on Z-axis, this will help us to understand what is already researched and where more research is needed.

We assigned a value between 0 and 1 , where 0 means that the literature does not talk about the dimension. For example, goal is containing two ends prevention and response, 1 means that literature is placed in the response box. We assume that 0.5 is a value where we place literature 
that talks about both prevention and response; literature deals with prevention only are placed where value is less than 0.5 . Nature of event is the only dimension in which we cannot find that event can be placed as 0.5 , since it is not possible that an event can be ongoing and rare at the same time.

Figure 3 shows the categorization of some exemplary risk literature along these dimensions. For example, some literature deals clearly with the nature of event as ongoing (e.g. Andriani \& Mckelvey, 2011; Maguire \& Hardy, 2013). Other literature, such as about goals, is segregated as few of the papers talk about prevention (i.e. Holt, 2004; Kaliprasad, 2006), few about response (i.e. Osipova \& Eriksson, 2011; Hwang et al., 2013) and some of them consider both prevention and response (i.e. Shen, 1997). Similarly, source (internal/external), literature contains both internal and external (Berkeley et al., 1991; Tah \& Carr, 2000; Gil, 2009; Kaplan \& Mikes, 2012) while some of the literature only discusses risks as external (i.e. Senge \& Carsedt, 2001; Senge et al., 2007). There is only on paper Brinkmann (2013) that deals with prevention as goal and internal and external as nature of event. The diagram indicates that research is mainly done on isolated subjects of either goals, nature of event and goals. Gaps exist along with the relationships between these subjects. These are indicated as research topics in need of a better understanding of risk.

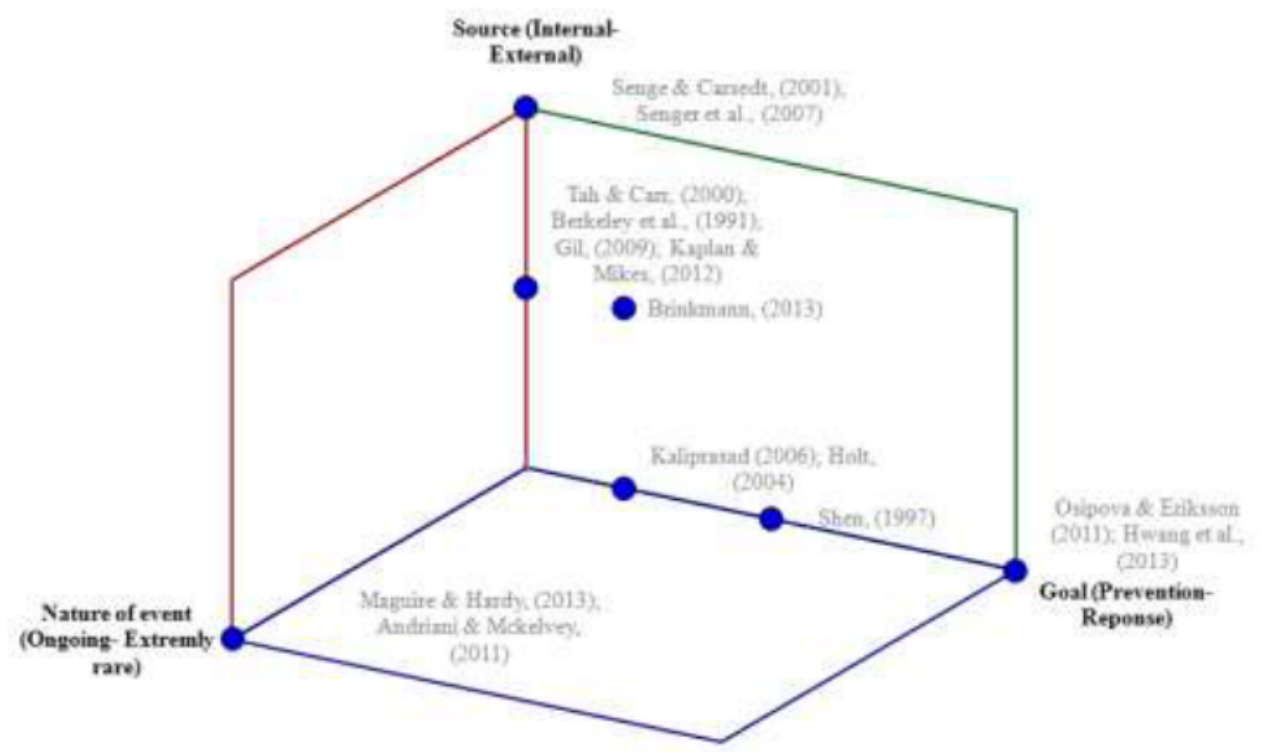

Figure 3 Risk literature diversity

Figure 4 shows the categorization of some exemplary literature on crisis. Weick, 1988; Pearson and Clair, 1998; Oh et al., 2013 deal with the nature of events, which are rare, but not extremely rare so we assign 0.7 to it. Najafbagy (2011) treats goal as a response, and Heath (1998); Hale et al. (2005) and Valackiene (2009), consider prevention and response both as goal. Mitroff et al. (1987) and Shrivastava and Mitroff (1987) address prevention as goal and describe internal and external sources of crises. Coombs and Holladay (1996), Milenkovic (2001), and Hensgen et al. (2006), address internal and external sources of crisis. Coombs (2007), is the only paper which deals with nature of event (rare) and internal and external both as a source of crisis.

The diagram shows that the crisis literature has started to look into cross-dimensional issues, as done by Coombs (2007). However, only one such paper was identified while the rest of the crisis literature seems to lack research on the combination of the source, nature and goal dimensions. 


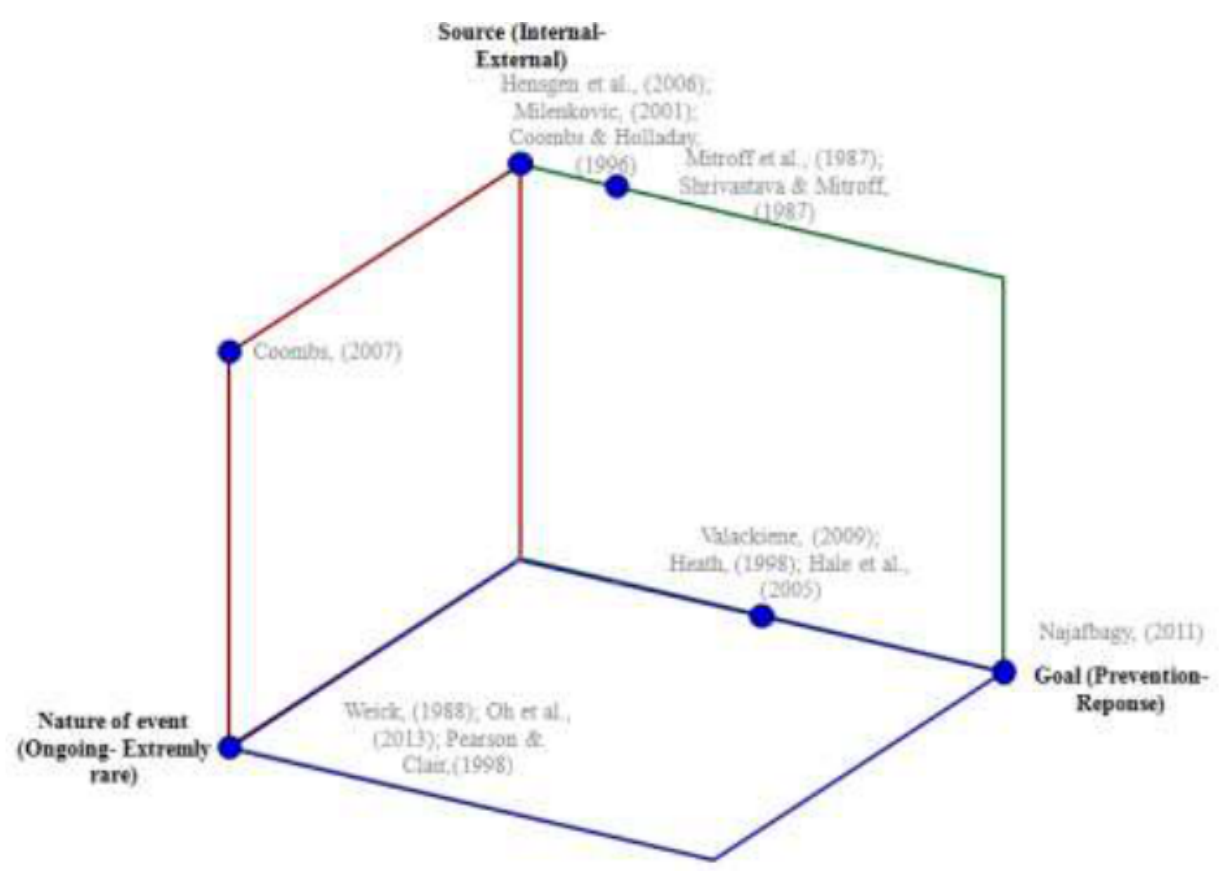

Figure 4 Crisis literature diversity

Figure 5 shows the categorization of some exemplary literature on disasters. The papers by Schenker-Wicki et al. (2010) and Smet et al. (2012) deal with the nature of event, since disaster is an extremely rare event so we assign 1 to it. We found papers like Cutter (2003), Altay and Green (2006) and Hristidis et al. (2010), dealing with response as goal while a few of the papers (i.e. Wallace \& Balogh, 1985) consider prevention as goal, whereas others consider prevention and response both as goal of disaster (e.g. Nateghi-A, 2000; Cronstedt, 2002; Moe \& Pathranarakul, 2006). Similar to the risk literature, disaster literature appears to be in need of more cross-dimensional research.

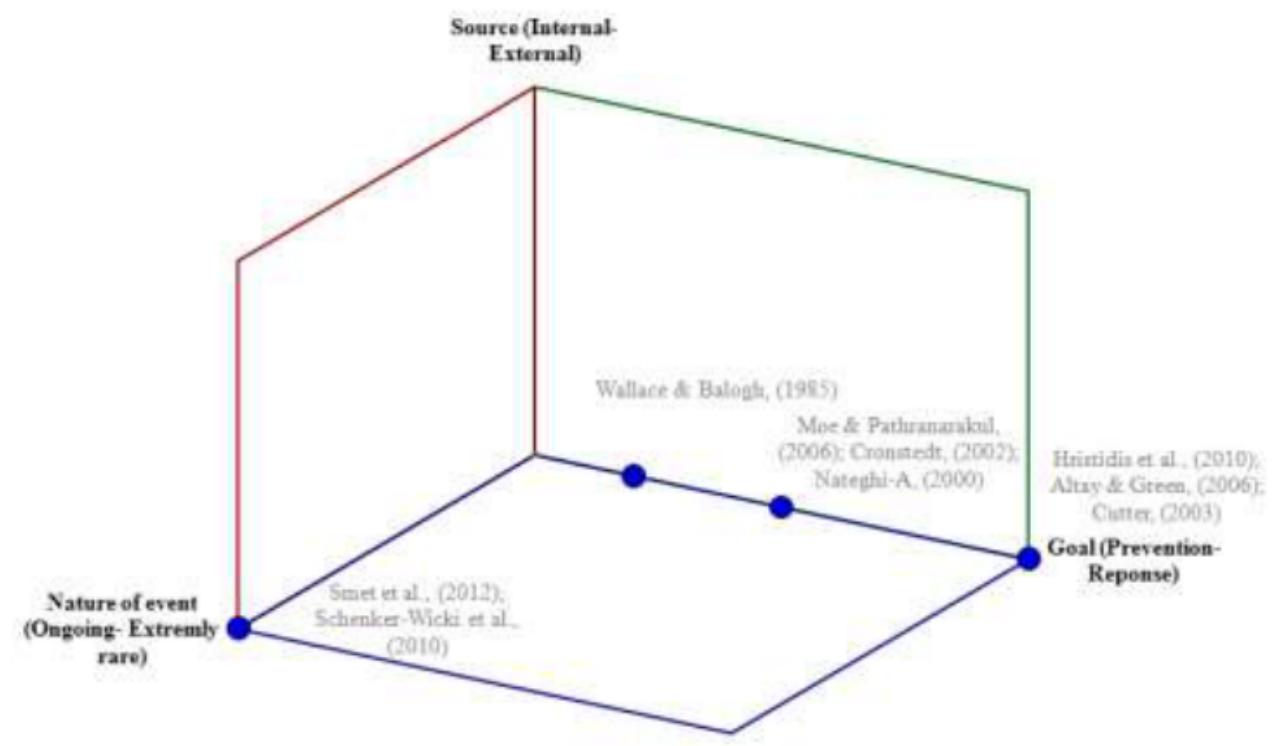

Figure 5 Disaster literature diversity 


\section{DISCUSSION}

Risk is not crisis and crisis is not a disaster. These terms are often associated with each other; they are not in fact completely synonyms, should not be used interchangeably. For example, Rosenthal and Hart (1991) considered crisis as high-risk events; Pearson and Clair (1998) described crisis preparedness from risk perception, whereas Pauchant et al. (1991) stated crisis as not a major risk. Quarantelli et al. (1988) used the term disaster crisis management and Rosenthal et al. (1991) described that different types of crisis events include natural and technological disasters. According to Simard and Laberge (2018) for crisis, a neutral term of risk is mostly used in project management literature and sometimes crises may be associated with disaster. Aforementioned illustrations represent that several studies have amalgamated the concepts of risk, crisis, and disaster. However, this paper attempts to develop a taxonomy of risk, crisis, and disaster, explain their historical development, and identify knowledge gaps for future research. The aim is to support a better understanding of the distinctiveness of the concepts of risk, crisis, and disaster. The taxonomy is developed to help practitioners and academics to understand the difference between risk, crisis, and disaster, that is, they can use the concept of, for example, crisis when appropriate and risk or disaster.

The evolutionary model shows the development over time, as well as the neighborhood concepts. This model supports our claim that risk, crisis, and disaster are different. Then the three concepts and their dimensions are modeled along a continuum to show the relationships between the concepts and their distinguishing dimensions. The key dimensions are the ones that make the differences more understandable. It helps researchers and practitioners to position their respective event on the continuum make sure that event correctly identified as either risk, or crisis or disaster, and then use Table 1 to identify appropriate managerial actions to prepare for, mitigate, or recover from the event.

Topics for future research are identified through 3D diagrams, distinguished by dimensions like nature of event, goal, and source for risk, crisis, and disaster. By positioning key literature within these diagrams, existing knowledge gaps are identified and suggested for future research. Interestingly, none of the identified publications addressed the sources of disasters. Hence, the topic is a candidate for future research.

\section{CONCLUSION}

Terminology confusion exists in the area of risk, crisis, and disaster. Literature reveals that scholars in different fields use the same terms to explain different phenomena. In other words, the term risk, crisis, and disaster in its current use are not referring to the same concept; they are different. Due to the peculiarity of risk, crisis, and disaster, the individuality of these concepts is diluted. We identified a number of dimensions that differentiate between risk, crisis, and disaster and presented an overview of fundamental differences among these concepts. Subsequently, we outlined taxonomy.

We can now answer the research questions:

RQ1: What is the difference between risk, crisis, and disaster?

Table 1 outlines the differences in through a taxonomy which distinguishes the concepts by their definition, management approach, management phases, characteristics, initiator, level of change/management, classification, nature, type, frequency, stakeholders, austerity, impact, scale, scope and magnitude. Based on this taxonomy, the concepts and their distinguishing dimensions are modeled in Figure 1 as a continuum from risk to disaster and the relationship with the distinguishing dimensions.

RQ2: What are the characteristics of each of these concepts? 
The characteristics in terms of evolutionary development are briefly introduced in Figure 2 by outlining and positioning the concepts against related other concepts over time. The particular characteristics of each of the three concepts are described in Table 1, which identifies risk as a concept that relates to relatively small, not devastating upheavals in daily work, whereas crisis threatens the survival of organizations, and disasters typically involve the loss of life and large scale devastation. Hence, the three concepts describe events of different magnitude, with each of them requiring specific actions for preparation, mitigation, and recovery.

RQ3: Which future research topics derive from an analysis of the three different concepts? By placing key publications in risk, crisis and disaster along the dimensions of origin (source), nature, and goals of an event, we identified knowledge gaps along the lines of interaction between the origin (source), nature, and goals in each of the three concepts. These constitute research topics for the future.

\subsection{Theoretical and managerial contribution}

This paper clarifies a long-standing confusion around the description of events with negative impact. To that end, we clarified the differences in origins, mitigations, and recovery of each of the concepts of risk, crisis, and disaster. For academics, this increase in conciseness contributes to a better understanding of the concepts, which allow for more precise and focused investigations in the future, with the potential to develop theories that are more concise.

Practitioners benefit from the reduction of ambiguity by being in a position to better describe the status of their organization or project and to identify actions appropriate for their particular situation. This includes taking managerial actions to develop risk mitigation for intraorganizational projects, or develop tactics to prevent crises, or develop more long-term strategies to handle and recover from disasters if they occur.

\subsection{Strengths and weaknesses}

The strengths of the study are in the simultaneous assessment of the three concepts, which allows to position them against each other and to develop clear definitions and distinguishing dimensions. At the same time, there could have been more dimensions considered, such as scope (predictability-unpredictability) and impact (success-survival). This is the limitation of the paper and meanwhile a potential area for future research. Other topics for future research are discussed in the respective section above and indicated in the answer to research question RQ3.

\subsection{Contribution to knowledge}

The findings of this study contribute to the risk, crisis and disaster literature, which has focused primarily on the individuality of these concepts and understanding difference among them. This article's contribution to knowledge lies in: a) a comprehensive and up-to-date literature review on risk, crisis and disaster, that documents the discrepancies in contemporary literature; b) a taxonomy of the three concepts, which allows to refresh the theoretical view of risk, crisis and disaster; c) A model that allows to identify an event as either risk, crisis or disaster, and the relationship with the associated dimensions like management approach, management phases, characteristics, initiator, level of change/management, classification, nature, type, frequency, stakeholders, austerity, impact, scale, scope and magnitude; d) a set of possible distinguishing dimensions to investigate through future research.

Researchers and academicians must be careful while using these concepts as they mean different things. We hope that this study sparks increased research attention pertaining to use these concepts with their real essence. 


\section{REFERENCES}

[1] Akintoye, A.S., \& MacLeod, M.J, Risk analysis and management in construction, International Journal of Project Management, 15(1),1997, pp 31-38.

[2] Alexander, D, The study of natural disasters, 1977-1997: Some reflections on a changing field of knowledge, Disasters, 21(4), 1997, pp 284-304.

[3] Altay, N., \& Green, W.G, OR/MS research in disaster operations management, European Journal of Operational Research, 175(1), 2006, pp 475-493.

[4] Andriani, P., \& Mckelvey, B, Managing in a Pareto world calls for thinking, Management, 14(2), 2011, pp 89-118.

[5] Ball, N, Some notes on defining disaster: Suggestions for a disaster continuum, Disasters, 3(1), 1979, pp 3-7.

[6] Barki, H., Rivard, S., \& Talbot, J, Toward an assessment of software development risk, Journal of Management Information Systems, 10(2),1993, pp 203-225.

[7] Barton, L, Crisis in Organizations: Managing and Communicating in the Heat of Chaos, South-Western Publishing Company, Cincinnati, OH, 1992.

[8] Berkeley, D., Humphreys, P.C., \& Thomas, R.D, Project risk action management, Construction Management and Economics, 9(1), 1991, pp 3-17.

[9] Billings, R.S., Milburn, T.W., \& Schaalman, M.L, A model of crisis perception: A theoretical and empirical analysis, Administrative Science Quarterly, 25(2), 1980, pp 300-316.

[10] Blodgett, T.B., \& Dissmeyer, V.M, Are you ready to meet a disaster? Harvard Business Review, 83(3), 1983, pp 6-12.

[11] Boehm, B.W, Software risk management: Principles and practices, IEEE Software, 8(1), 1991, pp 32-41.

[12] Brinkmann, J, Combining risk and responsibility perspectives: First steps, Journal of Business Ethics, 112(4), 2013, pp 567-583.

[13] Cabedo, J. D., \& Tirado, J. M, The disclosure of risk in financial statement, Accounting Forum, 28(2), 2004, pp 181-200.

[14] Carone, A., \& Lorio, L.D, Crisis management: An extended reference framework for decision makers, Journal of Business Continuity \& Emergency Planning, 6(4), 2013, pp 347359.

[15] Chase, W. H, Issue Management - Origins of the Future, Issue Action Publications, Stamford, CT, 1984

[16] Coleman, L, Frequency of man-made disasters in the 20th century, Journal of Contingencies and Crisis Management, 4(1), 2006, pp 3-11.

[17] Coombs W.T., \& Holladay, S.J, Communication and attributions in a crisis: An experimental study in crisis communication, Journal of Public Relations Research, 8(4), 1996, 279-295.

[18] Coombs, W. T. Ongoing Crisis Communication: Planning, Managing, and Responding, Sage Publications, London, 1999

[19] Coombs, W.T, West pharmaceutical's explosion: Structuring crisis discourse knowledge, Public Relations Review, 30(4), 2004, pp 467-473.

[20] Coombs, W.T, Protecting organization reputations during a crisis: The development and application of situational crisis communication theory. Corporate Reputation Review, 10(3), 2007, 163-176.

[21] Cronstedt, M, Prevention, preparedness, response, recovery- an outdated concept?, Australian Journal of Emergency Management, 17(2), 2002, 10-13.

[22] Cutter, S.L, GI science, disasters, and emergency management, Transactions in GIS, 7(4), 2003, 439-445. 
[23] Dean, M.D., \& Payne, D.M, Disaster management: An ethical review and approach, International Journal of Emergency Management, 9(2), 2013, pp 113-126.

[24] Dey, P. Dr, Managing risks of large scale construction projects, Cost Engineering, 51(6), 2009, 23-27.

[25] Dutton, J.E, The processing of crisis and non-crisis strategic issues, Journal of Management Studies, 23(5), 1986, 501-517.

[26] Edwards, P.G., \& Bowen, P.A, Risk and risk management in construction: A review and future direction for research, Engineering Construction and Architectural Management, 5(4), 1998, pp 339-349.

[27] Egelhoff, W. G., \& Sen, F, An information-processing model of crisis management, Management Communication Quarterly, 5(4), 1992, pp 443-484.

[28] Emergency disasters database, available at: http://www.em-dat.net (accessed 26 November 2013).

[29] Fearn-Banks, K, Crisis Communication: A Casebook Approach, Lawrence Erlbaum Associates Publishers, Mahwah, NJ, 1996

[30] Galbraith, J.R, Designing Complex Organizations, Addison-Wesley, Reading, MA, 1973

[31] Galbraith, J. R, Organization design, Addison-Wesley, Readings, MA, 1977

[32] Gephart, R.P., Jr. Van Maanen, J., \& Oberlechner, T, Organizations and risk in late modernity, Organization Science, 30(2-3), 2009, pp 141-155.

[33] Gil, N, Developing cooperative project client-supplier relationships: How much to expect from relational contracts? California Management Review, 51(2), 2009, pp 144-170.

[34] Hale, J.E., Dulek, R.E., \& Hale, D.P, Crisis response communication challenges: Building theory from qualitative data, Journal of Business Communication, 42(2), 2005, pp 112-134.

[35] Hällgren, M., \& Wilson, T.L, The nature and management of crises in construction projects: Projects - as - practice observations, International Journal of Project Management, 26(8), 2008, pp 830-838.

[36] Hart, P'T., Rosenthal, U., \& Kouzmin, A, Crisis decision making: The centralization thesis revisited, Administration \& Society, 25 (1), 1993, pp 12-45.

[37] Heath, R, Dealing with the complete crisis - The crisis management shell structure, Safety Science, 30(1-2), 1998, pp 139-150.

[38] Heath, R.L., Lee, J., \& Ni, L, Crisis and risk approaches to emergency management planning and communication: The role of similarity and sensitivity, Journal of Public Relations Research, 21(2), 2009, pp 123-141.

[39] Hensgen, T., Desouza, K.C., \& Durland, M, Initial crisis agent-response impact syndrome (ICARIS), Journal of Contingencies and Crisis Management, 14(1), 2006, pp 190-198.

[40] Hermann, C.F, Some consequences of crisis which limit the viability of organizations, Administrative Science Quarterly, 8(1), 1963, pp 61-82.

[41] Hobday, M, The project-based organization: An ideal form for managing complex products and systems? Research Policy, 29(7-8), 2000, pp 871-893.

[42] Holt, R, Risk management: The talking cure, Organization, 11(2), 2004, pp 251-270.

[43] Hristidis, V., Chen, Shu-Ching, Li, T., Luis, S., \& Deng, Y, Survey of data management and analysis in disaster situation, The Journal of Systems and Software, 83(10), 2010, pp 17011714.

[44] Hwang, B-G., Zhao, X., \& Toh, L.P, Risk management in small construction projects in Singapore: Status, barriers and impact, International Journal of Project Management, 32(1), 2013, pp 1-9.

[45] Dr. Firas Khairy Jaber, Establishing Risk Management Factors for Construction Projects in Iraq, International Journal of Advanced Research in Engineering and Technology (IJARET) Volume 6, Issue 1, Jan 2015, pp. 36-50 
[46] Jaafari, a, Management of risks, uncertainties and opportunities on projects: Time for fundamental shift, International Journal of Project Management, 19(2), 2001, pp 89-101.

[47] Jaques, T, Issue management and crisis management: An integrated, non-linear, relational construct, Public Relations Review, 33(22), 2007, pp 147-157.

[48] Jaques, T, Issue management as a post-crisis discipline: Identifying and responding to issue impacts beyond the crisis, Journal of Public Affairs, 9(1), 2009, pp 35-44.

[49] Julca, A, Natural disasters with un-natural effects: Why? Journal of Economics Issues, 46(2), 2012, pp 499-510.

[50] Kaliprasad, M, Proactive risk management, Cost Engineering, 48(2), 2006, pp 26-35.

[51] Kaplan, R.S, The words of risk analysis, Risk Analysis, 17(4), 1997, pp 407-417.

[52] Kaplan, R.S., \& Mikes, A, Managing risks: A new framework, Harvard Business Review, 90(6), 2012, pp 49-60.

[53] Dr. Shivakumar Deene. Assest Liability Management in Indian Banking Industry - with Special Reference to Interest Rate Risk Management in Vijaya Bank. International Journal of Advanced Research in Management, 6(3), 2015, pp. 122-134.

[54] Knight, F.H, Risk, Uncertainty and Profit, Hart, Schaffner \& Marx; Houghton Mifflin Co, Boston, MA, 1921.

[55] Kouzmin, A, Crisis management in crisis?, Administrative Theory and Praxis, 30(2), 2008, pp 155-183.

[56] Krane, H.P., Olsson, N.O.E., \& Rolstadås, A, How project manager-project owner interaction can work within and influence project risk management, Project Management Journal, 43(2), 2012, Pp 54-67.

[57] Linsley, P. M., \& Shrives, P. J, Risk reporting: A study of risk disclosure in the annual reports of UK companies, The British Accounting Reviews, 38(4), 2006, pp 387-404.

[58] Loosemore, M, Organizational behaviour during a construction crisis, International Journal of Project Management, 16(2), 1998, pp 115-121.

[59] Maguire, S., \& Hardy, C, Organizing processes and the construction of risk: A discursive approach, Academy of Management Journal, 56 (1), 2013, 231-255.

[60] McConnell, A., \& Drennan, L, Mission impossible? Planning and preparing for crisis, Journal of Contingencies and Crisis Management, 14(2), 2006, pp 59-70.

[61] Meyer, A.D, Adapting to environmental jolts, Administrative Science Quarterly, 27(2), 1982, pp 515-537.

[62] Meyer, A.D., Brooks, G.R., \& Goes, J.B, Environmental jolts and industry revolutions: Organizational responses to discontinuous change, Strategic Management Journal, 11 (4), 1990, pp 93-110.

[63] Adesh Chandra, Anurag Singh \& Ishan Rastogi, Understanding Enterprise Risk Management and Fair Model with the Help of a Case Study, International Journal of Computer Engineering \& Technology (IJCET), Volume 3, Issue 3, October - December (2012), pp. 300-311

[64] Meyer, A. D., Loch, C.H., \& Pich, M.T, Managing project uncertainty: From variation to chaos, MIT Sloan Management Review, 43 (2), 2002, 60-67.

[65] Milburn, T.W., Schuler, R.S., \& Watman, K.H, Organizational crisis: Part II: Strategies and responses, Human Relations, 36(12), 1983, pp 1161-1180.

[66] Milenkovic, G, Early warning of organizational crises: A research project from the international air express industry, Journal of Communication Management, 5(4), 2001, pp 360-373.

[67] Mitroff, I.I., Shrivastava, P., \& Udwadia, F, Effective crisis management, The Academy of Management Executive, 1(2), 1987, pp 283-292. 
[68] Mitroff, I. I, Crisis Management and Environmentalism: A Natural Fit, California Management Review, 36(4), 1994, pp 101-113.

[69] Moe, T.L., \& Pathranarakul, P, An integrated approach to natural disaster management: Public project management and its critical success factors, Disaster Prevention and Management, 15(5), 2006, pp 396-413.

[70] Moe, T. L., Gehbauer, F., Senitz, S., \& Mueller, M, Balanced scorecard for natural disaster management projects, Disaster Prevention and Management, 16(3), 2007, pp 785-806.

[71] Mutter, J. C, Preconditions of disaster, premonitions of tragedy, Social Research, 75(3), 2008, pp 691-724.

[72] Najafbagy, R, The crisis management capabilities and preparedness of organizations: A study of Iranian Hospitals, International Journal of Management, 28(22), 2011, pp 573-584.

[73] Nateghi-A.F, Disaster mitigation strategies in Tehran, Iran, Disaster Prevention and Management, 9(3), 2000, pp 205-211.

[74] Nieto-Morote, A., \& Ruz-Vila, F, A fuzzy approach to construction project risk assessment, International Journal of Project Management, 29(2), 2011, pp 220-231.

[75] Norris, F.H., Friedman, M.J., \& Watson, P.J, 60,000 disaster victims speak: Part I. An empirical review of the empirical literature, 1981-2001, Psychiatry, 65(3), 2002, pp 207-239.

[76] Oh, O., Agrawal, M., \& Rao, H.R, Community intelligence and social media services: A rumor theoretical analysis of tweets during social crisis, MIS Quarterly, 37(2), 2013, pp 407426.

[77] Osipova, E., \& Eriksson, P.E, How procurement options influence risk management in construction projects, Construction Management and Economics, 29(11), 2011, pp 11491158.

[78] Pampel, F.C Disaster response, Facts on file, New York, 2008

[79] Pauchant, T.C. Ian I. Mitroff, I.I., \& Lagadec, P, Toward a Systemic Crisis Management Strategy: Learning from the Best Examples in the US, Canada and France, Industrial Crisis Quarterly, 5(3), 1991, pp 209-232.

[80] Pearson, C. M., \& Mitroff, I. I, from crisis prone to crisis prepared: A framework for crisis management, Academy of Management Executive, 7(1), 1993, pp 48-59.

[81] Pearson, C.M., \& Clair J.A, Reframing crisis management, Academy of Management Review, 23(1), 1998, pp 59-76.

[82] Pender, S, Managing incomplete knowledge: Why risk management is not sufficient, International Journal of Project Management, 19(2), 2001, pp 79-87.

[83] Ponis, S.T., \& Koronis, E, A knowledge management process-based approach to support corporate crisis management, Knowledge and Process Management, 19(3), 2012, pp 148159.

[84] Project Management Institute., A Guide to the Project Management Body of Knowledge, 5th edition, Project Management Institute, Inc, Newtown Square, PA, USA, 2013

[85] Quarantelli, E.L, Disaster crisis management: A summary of research findings, Journal of Management Studies, 25(4), 1988, pp 373- 385.

[86] Ray, S. J, Strategic Communication in Crisis Management: Lessons from the Airline Industry, Praeger, London, 1999.

[87] Raz, T., Shenhar, A. J., \& Dvir, D, Risk management, project success, and technological uncertainty, $R \& D$ Management, 32(2), 2002, pp 101-109.

[88] Regester, M., \& Larkin, J, Risk Issues and Crisis Management - A Casebook of Best Practice, 2nd edition, Kogan Page, London, 2002

[89] Reilly, A.H, Are organizations ready for crisis? A managerial scorecard, Columbia Journal of World Business, 22(1), 1987, pp 79-88. 
[90] Robert, B., \& Lajtha, C, A new approach to crisis management, Journal of Contingencies and Crisis Management, 10(4), 2002, pp 181-191.

[91] Rosenthal, U., \& Hart, P, Experts and Decision Makers in Crisis Situations, Knowledge: Creation, Diffusion, Utilization, 12(4), 1991, pp 350-372.

[92] Rosenthal, U., Hart, P., \& Kouzmin, A, the Bureau-Politics of Crisis Management, Public Administration, 69(2), 1991, 211-233.

[93] Schenker-Wicki, A., Inauen, M., \& Olivares, M, Unmastered risks: From crisis to catastrophe an economic and management insight, Journal of Business Research, 63(4), 2010, pp 337-346.

[94] Seeger, M.W., Sellnow, T.L., \& Ulmer, R.R, Communication, organization and crisis, Sage publications, Thousand Oaks, CA, 1998.

[95] Seeger, M.W, Chaos and crisis: Proposition for general theory of crisis communication, Public Relations Review, 28(4), 2002, pp 329-337.

[96] Senge, P.M., \& Carstedt, G, Innovating our way to the next industrial revolution, MIT Sloan Management Review, 42(2), 2001, pp 24-38.

[97] Senge, P.M., Lichtenstein, B. B., Kaeufer, K., Bradbury, H., \& Carroll, J.S, Collaborating for systemic change, MIT Sloan Management Review, 48(2), 2007, pp 44-53.

[98] Shaluf, I.M., Ahmadun, F-Razi., \& Said, A.M, A review of disaster and crisis, Disaster Prevention and Management, 12(1), 2003, pp 24-32.

[99] Shen, L.Y, Project risk management in Hong Kong, International Journal of Project Management, 15(2), 1997, pp 101-105.

[100] Shrivastava, P., \& Mitroff, I.I, Strategic management of corporate crises, Columbia Journal of World Business, 22(1), 1987, pp 5-11.

[101] Sicotte, H., \& Bourgault, M, Dimensions of uncertainty and their moderating effect on new product development project performance, $R \& D$ Management, 38(5), 2008, pp 468-479.

[102] Simard, M., \& Laberge, D, Development of a crisis in a project: A process perspective, International Journal of Managing Projects in Business, 11(3), 2018, pp 806-826.

[103] Sine, W.D., \& David, R.J, Environmental jolts, institutional change, and the creation of entrepreneurial opportunity in the US electric power industry, Research Policy, 32(2), 2003, pp 185-207.

[104] Siriwardena, M., Malalgoda, C., Thayaparan, M., Amaratunga, D., \& Keraminiyage, K. , Disaster resilient built environment: Role of lifelong learning and the implications for higher education, International Journal of Strategic Property Management, 17(2), 2013, pp 174187.

[105] Smet, H., Lagadec, P., \& Leysen, J, Disasters out of the box: A new ballgame?, Journal of Contingencies and Crisis Management, 20(3), 2012, pp 138-148.

[106] Smith, K, Environmental hazards: Assessing risk and reducing disaster, 4th edition, Routledge, London and New York, 2004.

[107] Solomon, J. F., Solomon, A., Norton, S.D., \& Joseph, N.L, A conceptual framework for corporate risk disclosure emerging from the agenda for corporate governance reform, British Accounting Review, 32(4), 2000, pp 447-478.

[108] Starbuck, W.H., Greve, A., \& Hedberg, B. L.T, Responding to crisis, Journal of Business Administration, 9(2), 1978, pp 112-137.

[109] Staw, B.M., Sandelands, L.E., \& Dutton, J. E, Threat-rigidity effects in organizational behavior: A multilevel analysis, Administrative Science Quarterly, 26(4), 1981, pp 501-524.

[110] Tah, J.H.M., \& Carr, V, A proposal for construction project risk assessment using fuzzy logic, Construction Management and Economics, 18(4), 2000, pp 491-500.

[111] Tah, J.H.M., \& Carr, V, towards a framework for project risk knowledge management in the construction supply chain, Advances in Engineering Software, 32(10-11), 2001, pp 835-846. 
[112] Taleb, N.N, The Black Swan: The Impact of the Highly Improbable, 1st edition, Random House \& Allen Lane, US \& UK, 2007.

[113] Turner, B.A, The organizational and inter organizational development of disasters, Administrative Science Quarterly, 21(3), 1976, pp 378-397.

[114] Ulmer, R.R., \& Sellnow, T.L, Crisis management and the discourse of renewal: Understanding the potential for positive outcomes of crisis, Public Relations Review, 28(4), 2002, pp 361-365.

[115] United Nations, International strategy for disaster reduction, available at: https://www.unisdr.org/ (accessed 25 January 2014), 2006.

[116] Valackiene, A, Theoretical model of employee social identification in organization managing crisis situations, Engineering Economics, 4 (64), 2009, pp 95-102.

[117] Valackiene, a, Theoretical substation of the mode for crisis management in organization, Engineering Economics, 21(2), 2011, pp 78-90.

[118] Veil, S.R, Mindful learning in crisis management, Journal of Business Communication, 48(2), 2011, pp 116-147.

[119] Wallace, W., \& Balogh, F. D, Decision support systems for disaster management, Public Administration Review, 45, 1985, pp 134-146.

[120] Wan, W.P., \& Yiu, D.W, from crisis to opportunity: Environmental jolt, corporate acquisitions, and firm performance, Strategic Management Journal, 30(7), 2009, pp 791801.

[121] Wei, J., Zhao, D., \& Liang, L, Estimating the growth model of news stories on disasters, Journal of the American Society for Information Science and Technology, 60(9), 2009, 17411755.

[122] Weick, K.E, Enacted sense making in crisis situation, Journal of Management Studies, 25(4), 1988, pp 305-317.

[123] Wideman, R.M, Risk management, Project Management Journal, 17(4), 1986, pp 20-26.

[124] Williams, S, Rethinking the nature of disaster: From failed instruments of learning to a postsocial understanding, Social Forces, 87 (2), 2008, pp 1115-1138.

[125] Wisner, B., Blaaikie, P., Cannon, T., \& Davis, I, at risk: natural hazards, people's vulnerability and disasters, 2nd edition. Routledge, London, 2003

[126] Yi, P., George, S.K., Paul, J.A., \& Lin, L, Hospital capacity planning for disaster emergency management, Socio-Economic Planning Sciences, 44(3), 2010, pp 151-160.

[127] Yosha, B, Make it not go wrong, Industrial Engineer, 44(6), 2012, pp 36-41.

[128] Zhang, H, Two schools of risk analysis: A review of past research on project risk, Project Management Journal, 42(4), 2011, pp 5-18.

\section{APPENDIX A}

Table 2 Overview of key publications

\begin{tabular}{|l|l|l|l|}
\hline Key publications & Motivation of study & Methodology & $\begin{array}{l}\text { Category } \\
\text { Risk (R) } \\
\text { Crisis (C) } \\
\text { Disaster (D) }\end{array}$ \\
\hline Knight (1921) & $\begin{array}{l}\text { To unpack the distinction between risk and } \\
\text { uncertainty. }\end{array}$ & Theoretical & R \\
\hline Raz et al. (2002) & $\begin{array}{l}\text { To explore the variations of risk management } \\
\text { techniques and suggest principles for a better } \\
\text { selection of such techniques and better development } \\
\text { of specific risk management tools in the future as } \\
\text { well as to understand the relationship between types } \\
\text { and application of risk management practices and } \\
\text { contribution of these practices to success. }\end{array}$ & Quantitative (Survey) & $\mathrm{R}$ \\
\hline
\end{tabular}




\begin{tabular}{|c|c|c|c|}
\hline Key publications & Motivation of study & Methodology & $\begin{array}{l}\text { Category } \\
\text { Risk (R) } \\
\text { Crisis (C) } \\
\text { Disaster (D) } \\
\end{array}$ \\
\hline $\begin{array}{l}\text { Gephart et al. } \\
(2009)\end{array}$ & $\begin{array}{l}\text { To enhance the field of organization studies by } \\
\text { encouraging to focus attention on risk and risk } \\
\text { management as a mean to enlarge and enrich the } \\
\text { field of organization studies. }\end{array}$ & Theoretical & $\mathrm{R}$ \\
\hline $\begin{array}{l}\text { Krane et al. } \\
(2012)\end{array}$ & $\begin{array}{l}\text { he purpose of this article is to study the interaction } \\
\text { between the project } \\
\text { owners and management team regarding risk } \\
\text { management in each of seven } \\
\text { large projects, and in particular whether there are } \\
\text { differences in the man- } \\
\text { agement of strategic and operational risks. } \\
\text { he purpose of this article is to study the interaction } \\
\text { between the project } \\
\text { owners and management team regarding risk } \\
\text { management in each of seven } \\
\text { large projects, and in particular whether there are } \\
\text { differences in the man- } \\
\text { agement of strategic and operational risks. } \\
\text { purpose of this article is to study the interaction } \\
\text { between the project } \\
\text { owners and management team regarding risk } \\
\text { management in each of seven } \\
\text { large projects } \\
\text { To examine how different motivations among actors } \\
\text { around projects are handled and to study the } \\
\text { interaction between the project actors (owners and } \\
\text { management team) regarding risk management. }\end{array}$ & $\begin{array}{l}\text { Qualitative (interviews and } \\
\text { document studies) and } \\
\text { quantitative (risk register } \\
\text { analysis). Study } 7 \text { large } \\
\text { projects }\end{array}$ & $\mathrm{R}$ \\
\hline $\begin{array}{l}\text { Maguire and } \\
\text { Hardy (2013) }\end{array}$ & $\begin{array}{l}\text { Examine organizing processes through which } \\
\text { products "become" risky or, for that matter, safe. }\end{array}$ & $\begin{array}{l}\text { Qualitative (Case studies: } \\
\text { publicly available data, } \\
\text { government web portal, and } \\
\text { websites ) }\end{array}$ & $\mathrm{R}$ \\
\hline Hermann (1963) & $\begin{array}{l}\text { To explore how certain responses to crisis may } \\
\text { hinder an organization's viability, the paper will } \\
\text { offer a series of interrelated propositions or a model. }\end{array}$ & $\begin{array}{l}\text { Propositions and illustrative } \\
\text { material (case studies) }\end{array}$ & $\mathrm{C}$ \\
\hline Turner (1976) & $\begin{array}{l}\text { To consider a manner in which high-quality } \\
\text { intelligence could be used to identify the conditions } \\
\text { that foster the failure of foresight. }\end{array}$ & $\begin{array}{l}\text { Qualitative (Observation: } \\
\text { behavior pattern and } \\
\text { information condition and } \\
\text { reports: In which it was easy } \\
\text { in official inquiry to attribute } \\
\text { the failure, reports of } \\
\text { incidents were analyzed) }\end{array}$ & $\mathrm{C}$ \\
\hline $\begin{array}{l}\text { Billings et al. } \\
\text { (1980) }\end{array}$ & $\begin{array}{l}\text { To review and evaluate Hermann's model (surprise, } \\
\text { short decision time, threat to valued goals) of crisis } \\
\text { and to develop a revised model from previous } \\
\text { theoretical and empirical research and to analyze the } \\
\text { individual decision maker's perception of a crisis, } \\
\text { which is related to the organizational response in } \\
\text { several ways. }\end{array}$ & $\begin{array}{l}\text { Case study (a case where } \\
\text { crisis occurs) and survey: } 250 \\
\text { of the largest profit-making } \\
\text { organizations and to } 250 \\
\text { educational institutions. }\end{array}$ & $\mathrm{C}$ \\
\hline Dutton (1986) & $\begin{array}{l}\text { To reveal how crisis strategic issues are processed } \\
\text { differently from non-crisis issues in organizations. }\end{array}$ & $\begin{array}{l}\text { Single case study (intensive } \\
\text { study of five real-time } \\
\text { strategic issues processed by } \\
\text { a single organization over a } \\
\text { 5-year time period and } \\
\text { interviews) }\end{array}$ & $\mathrm{C}$ \\
\hline $\begin{array}{l}\text { Quarantelli } \\
(1988)\end{array}$ & $\begin{array}{l}\text { To summarizes and highlights the major research } \\
\text { findings that have been established about } \\
\text { organizational behavior at the emergency stage of } \\
\text { community disasters. }\end{array}$ & Literature review & $\mathrm{C}$ \\
\hline
\end{tabular}




\begin{tabular}{|c|c|c|c|}
\hline Key publications & Motivation of study & Methodology & $\begin{array}{l}\text { Category } \\
\text { Risk (R) } \\
\text { Crisis (C) } \\
\text { Disaster (D) }\end{array}$ \\
\hline Weick (1988) & $\begin{array}{l}\text { To explore the complications of a delicate trade-off } \\
\text { between dangerous action, which produces } \\
\text { understanding and safe inaction, which produce } \\
\text { confusion. }\end{array}$ & Literature review & $\mathrm{C}$ \\
\hline $\begin{array}{l}\text { Fearn-Banks } \\
\text { (1996) }\end{array}$ & $\begin{array}{l}\text { To understand how organization, companies and } \\
\text { individual cope with communication aspects of } \\
\text { crisis management. }\end{array}$ & $\begin{array}{l}\text { Case studies (interviews, } \\
\text { blogs, and newspaper) }\end{array}$ & $\mathrm{C}$ \\
\hline $\begin{array}{l}\text { Pearson and } \\
\text { Clair (1998) }\end{array}$ & $\begin{array}{l}\text { To illustrate, integrate a multidisciplinary approach } \\
\text { to crisis management research, using psychological, } \\
\text { social-political, and technological-structural } \\
\text { research perspectives. Build definitions of } \\
\text { "organizational crisis" and "crisis management," and } \\
\text { developed a comprehensive model of the crisis } \\
\text { management process that reflects psychological, } \\
\text { social-political, and technological-structural } \\
\text { assumptions. }\end{array}$ & Theoretical (propositions) & $\mathrm{C}$ \\
\hline $\begin{array}{l}\text { Seeger et al. } \\
(1998)\end{array}$ & $\begin{array}{l}\text { Define organizational crisis, examine the role of } \\
\text { communication in crisis and explore various } \\
\text { departmental approaches used to describe crisis. }\end{array}$ & Literature review & $\mathrm{C}$ \\
\hline Coombs (1999) & $\begin{array}{l}\text { Provides an integrated and multi-disciplinary } \\
\text { approach to the entire crisis communication process } \\
\text { and explains how crisis management can prevent or } \\
\text { reduce the threats of a crisis, and provides } \\
\text { guidelines for how best to act and react in an } \\
\text { emergency situation. }\end{array}$ & Case studies & $\mathrm{C}$ \\
\hline Oh et al. (2013) & $\begin{array}{l}\text { To explore the information quality issue in the } \\
\text { context of social crises and media crises and } \\
\text { conceptualize the participatory social reporting } \\
\text { phenomenon as collective intelligence and } \\
\text { information processing to make sense, cope with, } \\
\text { and adapt to situational and informational } \\
\text { uncertainties under crises. }\end{array}$ & $\begin{array}{l}\text { Quantitative (research model, } \\
\text { hypothesis) and qualitative } \\
\text { (test hypothesis on three } \\
\text { cases using tweeter data set) }\end{array}$ & $\mathrm{C}$ \\
\hline Ball (1979) & $\begin{array}{l}\text { To explore the definition of two key concepts: } \\
\text { natural disaster and vulnerability. }\end{array}$ & Literature review & $\mathrm{D}$ \\
\hline $\begin{array}{l}\text { Alexander } \\
(1997)\end{array}$ & $\begin{array}{l}\text { To develop a disaster continuum and position } \\
\text { disaster in the continuum from acute to chronic }\end{array}$ & Literature review & $\mathrm{D}$ \\
\hline $\begin{array}{l}\text { Wisner et al. } \\
(2003)\end{array}$ & $\begin{array}{l}\text { To examine the significance of the human factor is } \\
\text { as much of a cause of disasters as the natural } \\
\text { environment. }\end{array}$ & $\begin{array}{l}\text { Theoretical and case studies } \\
\text { for illustration }\end{array}$ & $\mathrm{D}$ \\
\hline $\begin{array}{l}\text { Altay and Green } \\
(2006)\end{array}$ & $\begin{array}{l}\text { To point out issues in disaster operations } \\
\text { management. }\end{array}$ & $\begin{array}{l}\text { Literature review and review } \\
\text { disaster database }\end{array}$ & $\mathrm{D}$ \\
\hline Coleman (2006) & $\begin{array}{l}\text { Understand the frequency and consequences of } \\
\text { natural disasters; comprehensive understanding of } \\
\text { probable incidence and damages. To quantify } \\
\text { frequency, nature, and change in disasters in } \\
\text { developed economies during the 20th century. }\end{array}$ & $\begin{array}{l}\text { Literature review and disaster } \\
\text { database are used to analyze } \\
\text { two disasters in Australia. }\end{array}$ & $\mathrm{D}$ \\
\hline $\begin{array}{l}\text { Moe et al. } \\
(2007)\end{array}$ & $\begin{array}{l}\text { To develop an integrated approach for effectively } \\
\text { managing natural disasters by providing a } \\
\text { framework for effective natural disaster } \\
\text { management from a public project management } \\
\text { perspective proposes an integrated approach for } \\
\text { successfully and effectively managing disaster and } \\
\text { specifies a set of critical success factors for } \\
\text { managing disaster-related public projects. }\end{array}$ & $\begin{array}{l}\text { Case study of a tsunami } \\
\text { (Thailand) }\end{array}$ & $\mathrm{D}$ \\
\hline
\end{tabular}




\section{APPENDIX B}

\section{Related concepts}

Uncertainty: An uncertainty is defined as "a difference between the amount of information required to perform the task and the amount of information possessed by the organization" (Galbraith, 1977: 36-37). Uncertainty is hard to predict and control. It can be described as the difference between the information one has and the information one needs to complete a task (Galbraith, 1973). Knight (1921) first distinguishes between risk and uncertainty. Risk is measurable and insurable while uncertainty is unmeasurable and uninsurable. It has been argued that the term 'risk' is mostly associated with threats and 'known unknowns', leaving positive sides of risk. Uncertainty, on the other hand, has a broader perspective and focuses on both positive and negative effects as well as they are 'unknown unknowns'. Risk refers to those situations in which probabilities of potential outcomes are known, in contrast to uncertainty, for which probabilities of possible outcomes are unknown (Knight, 1921). Risk is assumed that reality is known, predictable, and measurable whereas uncertainty is the origin of complexity or unpredictability (Holt, 2004) which cannot be reduced by risk management (Pender, 2011) because it is unknown, unpredictable, and immeasurable.

Hazard: Disasters are different from hazards (Wisner et al., 2003). Hazards are the potential threats to people and things they valued. Hazard could be earthquake, tornadoes, blizzards, floods, drought, industrial plant failure, terrorism, and air pollution. Disasters, on the other hand, are the outcome of hazards (Cutter, 2003). Considerable damage is a requirement of disaster (Coleman, 2006). Disasters are, in fact, created by the interaction of many elements, if there is no population there is no disaster (Ball, 1979). Hazards transform into disasters through human agency (Mutter, 2008). Moreover, not every hazard is the source of a disaster. Disasters only occur when the human system intersects with a hazardous situation.

Environmental jolts: Jolts are change that is so sudden and it is a temporary disruption that leads to drastic change (Meyer et al., 1990). Jolts are difficult to foresee and its impacts on organizations are disruptive and often inimical (Meyer, 1982; Sine and David, 2003). The sudden environmental change put the organization in jeopardy (Starbuck et al., 1978; Staw et al., 1981). We postulate that environmental jolts are often viewed as a crisis, however, crisis could be internal and external but jolts are usually from the environment, which is external (Wan and Yiu, 2009).

Issues: An issue is "an unsettled matter which is ready for decision" (Chase, 1984: 38). Yet, there is reasonably broad acceptance of an issue as "a condition or event, either internal or external to the organization which, if it continues, will have a significant effect of the functioning or performance of the organization or on its future interests" (cited in Regester and Larkin, 2002: 42).

Black swan: A black swan is a highly improbable event with three essential properties: It is unpredictable (it is an outlier (an unusual event), as it lies outside the realm of regular expectations because nothing in the past can convincingly point to its possibility). Second, it carries a massive and extreme impact; and, finally, after the event, it is possible to come up with an explanation that makes it appear less random, and more explainable and predictable than it was. To sum up, three main ingredients of black swan are a rarity, extreme impact, and retrospective (not prospective). They occur rarely, with a totally unknown frequency, yet they carry large impact. Black swans (the highly improbable consequential event) are the rare events and outlier in a sense happens very often. Prediction is nearly impossible for these events (Taleb, 2007). 